\title{
The Export Ban of Raw Mineral Commodities of Indonesia: Resource Nationalism or a Means to Growth?
}

\author{
Rini Novrianti Sutardjo Tui \\ Graduate School of International Resource Sciences \\ Akita University \\ Akita, Japan
}

\author{
Prof. Tsuyoshi Adachi \\ Faculty of International Resource Sciences \\ Akita University \\ Akita, Japan
}

\begin{abstract}
Indonesia's export ban of raw mineral commodities is generally described as resource nationalism. As resource nationalism could bring prosperity to the country and the people, it also, when mismanaged, the could push the country to fall into the resource curse. Therefore, it is important to anticipate which way this export ban would lead Indonesia's economy. Simple parameters that can be used to measure the impact of the export ban are the economic freedom index and the values of GDP. We use the freedom index provided by The Heritage Foundation and GDP values provided by The World Bank and measure the values against the chronological events of implementation and release of regulations related to the export ban. The results indicate that despite how the export ban of Indonesia is often described as a part of resource nationalism, this export ban actually does not bring negative impact to the economy of Indonesia.
\end{abstract}

Keywords: resource nationalism, export ban, GDP, economic freedom index

\section{INTRODUCTION}

Resource nationalism is often considered as double-edged sword in term of economic development. In a way it could bring prosperity to the country and the people by maximizing benefit gained through the use of natural resources. In the other hand, when mismanaged, the resource nationalism could push the country to fall into the resource curse. One of the definitions that hit the core of resource nationalism is provided by $\mathrm{Li}$ and Adachi in 2017. Resource nationalism is essentially mandatory government intervention in natural resources business by political or economic means in order to benefit the nation and the people it on behalf of (Li \& Adachi, 2017).

When the government of Indonesia decided to release the new mining law, there is a subset of the law that could be considered as an event of resource nationalism. Article 103 of the Mining Law of The Republic of Indonesia Number 4 of 2009-Concerning Mineral and Coal Mining states that Production Operation Mining Permit holders and Special Mining Permit holders have to process and refine or smelt mining products domestically (Minister of Law and Human Right of The Republic of Indonesia, 2009). Consequently, this article leads to a trade policy that sets an export ban on the raw mineral commodities. This trade policy is supposedly to take place by at least January 12th 2014. However, it has been five years since that date, and the policy is kept delayed. The delay, directly and indirectly, would bring problems into the economy of Indonesia.

The chronology of the implementation of the export ban goes as following: in 2009, the underlying law for the export ban was released, which was the Mining Law of The Republic of Indonesia Number 4 of 2009-Concerning Mineral and Coal Mining. However, in 2014, another ministerial regulation, this time is Energy and Mineral Resource Ministerial Regulation Number 1 of 2014 was released. This regulation rules that instead of in 2014, the ban of exporting raw mineral commodities would take place in 2017. During 2013 to 2017, the mineral commodities could be exported in raw form in limited amount. In 2017, the Ministry of Energy and Mineral
Resources again released two ministerial regulations, Number 6 and Number 7 of 2017, which loosen up the export ban again. Then, in 2019, the government has stated to fully ban the export in raw form for nickel commodities specifically by January 2020. These rules for the export ban of raw mineral commodities are certainly confusing, especially for the mining companies and investors. In one hand, the government obligates the companies to invest and build their own smelters, in order to ensure that the raw minerals are processed and exported in processed forms. In other hand, the government also permits the companies to still export in raw form as long as the companies are paying the export duty. The ever changing rules of export ban needs to be analyzed to determine whether this export ban will bring the intended benefit as the government wants it to, or it will drive Indonesia to the trap of resource curse.

\section{LITERATURE REVIEW}

The very basic word definition defines policy as course or principle of action adopted or proposed by a government, party, business, or individual (Oxford, n.d.). Howlett (2014) states that policy design involved the effort to more or less systematically develop efficient and effective policies through the application of knowledge about policy means gained from experience, and reason, to the development and adoption of courses of action that are likely to succeed in attaining their desired goals or aims within specific policy contexts (Howlett, 2014). Basically the export ban is derived from the mining law. In addition to the aim to better optimize the benefit of the mineral commodities, it also indicates the intention of the government of Indonesia to increase control of the mineral resources. Ward (2009) has described a characteristic of resource nationalism as the tendency for states to take (or seek to take) direct and increasing control of economic activity in natural resource sectors (Ward, 2009). This characteristic is further explained by Wilson that established resource nationalism as occurrence where a natural-resource endowed country uses its legal jurisdiction over these resources to achieve some set of national development goals that would otherwise not obtain if their exploitation were left to international market processes. (Wilson, 2009). In the other 
hand, resource nationalism also could be explained as development and introduction of new policy by the government that is directed, among others, towards controlling natural monopolies and exerting macro-economic policy influence (Solomon, 2012). Therefore, it can be concluded that the export ban basically is treading upon the resource nationalism. As the resource nationalism has been explicated as double-edged sword, the export ban should be analyzed as to better explain its economic implication.

\section{RESULTS}

In term of how the new trade policy will affect the economy, first, we check whether this export ban could in fact be classified as a resource nationalism event. Previous research by $\mathrm{Li}$ and Adachi (2017) has classified the release of the Mining Law Number 4 as an occurrence of resource nationalism in lower middle and low income countries (Li \& Adachi, 2017). This finding then further expanded by analysis of Lowy Institute and United States Geological Survey that shows how Indonesia has become an exemplar of resource nationalism in this decade ( (United States Geological Survey, 2016), (Warburton, 2017)).

Then, we use the Heritage Index of Freedom. The Heritage Foundation develops Index of Economic Freedom, of which it examines economic policy developments in 186 countries. The index evaluates the rule of law, size of government, regulatory efficiency, and openness of markets (Heritage Organization, 2019). We take the index values of Indonesia for the year of 2000 to 2018, and compare them to the chronological dates of the implementation of the export ban. In Table 1, we mark the occurrence of regulations related to the export ban using 1 when there is a regulation released and 0 when there is no regulation released.

Table 1. Trade freedom index as compared to the occurrence of regulation-related resource nationalism

\begin{tabular}{|r|r|r|}
\hline Year & Indonesia's Index & Export Ban's Chronology \\
\hline 2000 & 55.2 & 0 \\
\hline 2001 & 52.5 & 0 \\
\hline 2002 & 54.8 & 0 \\
\hline 2003 & 55.8 & 0 \\
\hline 2004 & 52.1 & 0 \\
\hline 2005 & 52.9 & 0 \\
\hline 2006 & 51.9 & 0 \\
\hline 2007 & 53.2 & 0 \\
\hline 2008 & 53.2 & 0 \\
\hline 2009 & 53.4 & 1 \\
\hline 2010 & 55.5 & 0 \\
\hline 2011 & 56.0 & 0 \\
\hline 2012 & 56.4 & 0 \\
\hline 2013 & 56.9 & 0 \\
\hline 2014 & 58.5 & 1 \\
\hline 2015 & 58.1 & 0 \\
\hline 2016 & 59.4 & 0 \\
\hline 2017 & 61.9 & 1 \\
\hline 2018 & 64.2 & 0 \\
\hline
\end{tabular}

Setting the year of 2009 as the base year, we analyze the impact of the export ban's regulations towards the economic freedom index of Indonesia.

Table 2. Change in economic freedom index compared to the base year of 2009

\begin{tabular}{|c|r|}
\hline Year & Comparison to the Base Year \\
\hline 2000 & 1.03 \\
\hline 2001 & 0.98 \\
\hline 2002 & 1.03 \\
\hline 2003 & 1.04 \\
\hline 2004 & 0.98 \\
\hline 2005 & 0.99 \\
\hline 2006 & 0.97 \\
\hline 2007 & 1.00 \\
\hline 2008 & 1.00 \\
\hline 2009 & 1.00 \\
\hline 2010 & 1.04 \\
\hline 2011 & 1.05 \\
\hline 2012 & 1.06 \\
\hline 2013 & 1.07 \\
\hline 2014 & 1.10 \\
\hline 2015 & 1.09 \\
\hline 2016 & 1.11 \\
\hline 2017 & 1.16 \\
\hline 2018 & 1.20 \\
\hline & \\
\hline &
\end{tabular}

The increasing nature of the economic freedom index indicates that generally the releases of the regulations that relate to the export ban do not really affected the perceived freedom of economic of Indonesia. Throughout the time, the economic freedom is getting even higher score, indicating higher degree of freedom.

Further, we take the GDP of Indonesia into account. We use the Indonesia's GDP at purchaser's price, provided by the World Bank.

Table 3. GDP of Indonesia (Source: (The World Bank, n.d.)

\begin{tabular}{|c|c|}
\hline \multicolumn{1}{|c|}{ Year } & \multicolumn{1}{c|}{ GDP } \\
\hline 2000 & $1.65 \mathrm{E}+11$ \\
\hline 2001 & $1.6 \mathrm{E}+11$ \\
\hline 2002 & $1.96 \mathrm{E}+11$ \\
\hline 2003 & $2.35 \mathrm{E}+11$ \\
\hline 2004 & $2.57 \mathrm{E}+11$ \\
\hline 2005 & $2.86 \mathrm{E}+11$ \\
\hline 2006 & $3.65 \mathrm{E}+11$ \\
\hline 2007 & $4.32 \mathrm{E}+11$ \\
\hline 2008 & $5.1 \mathrm{E}+11$ \\
\hline
\end{tabular}




\begin{tabular}{|r|r|}
\hline 2009 & $5.4 \mathrm{E}+11$ \\
\hline 2010 & $7.55 \mathrm{E}+11$ \\
\hline 2011 & $8.93 \mathrm{E}+11$ \\
\hline 2012 & $9.18 \mathrm{E}+11$ \\
\hline 2013 & $9.13 \mathrm{E}+11$ \\
\hline 2014 & $8.91 \mathrm{E}+11$ \\
\hline 2015 & $8.61 \mathrm{E}+11$ \\
\hline 2016 & $9.32 \mathrm{E}+11$ \\
\hline 2017 & $1.02 \mathrm{E}+12$ \\
\hline 2018 & $1.04 \mathrm{E}+12$ \\
\hline
\end{tabular}

The Indonesia's GDP also indicates overall increase from the year of 2009. With a slight drop from the year of 2012 to 2015, the GDP is back on increasing from 2016.

\section{ACKNOWLEDGMENTS}

We would like to express our gratitude towards JICA C-BEST Program

\section{REFERENCES}

[1] Heritage Organization, 2019. 2019 Index of Economic Freedom, s.l.: Heritage Organization.

[2] Howlett, M., 2014. Policy Design. In: C. Halpern, P. Lascoumes \& P. Le Galès, eds. L'instrumentation et ses effets. Paris: Presses de Sciences Po., pp. 281-315.

[3] Li, W. \& Adachi, T., 2017. Quantitative estimation of resource nationalism by binary choice logit model for panel data. Resource Policy, Issue 53, pp. 247-258.

[4] Solomon, M., 2012. The Rise of Resource Nationalism: A Resurgence of State Control in an Era of Free Markets Or the Legitimate Search for a New Equilibrium?, Cape Town: Southern African Institute of Mining and Metallurgy.

[5] The World Bank, n.d. GDP (Current US\$) - Indonesia [Online] Available at: https://data.worldbank.org/indicator/NY.GDP.MKTP.CD

\section{CONCLUSIONS}

Despite how the export ban of Indonesia is often described as a part of resource nationalism, as indicated by both the economic trade index and GDP, this export ban actually does not bring negative impact to the economy of Indonesia. The international world still perceives Indonesia to have a moderate freedom of economic, and the economic is actually still growing as the GDP grows.

However, as this is a preliminary study, further research is needed to determine the economic impact brought to Indonesia's economy by the export ban. Since the economic freedom index and GDP are simplified measures of the economy, more parameters are needed to better resolve the impacts of the export ban of raw mineral commodities of Indonesia.

?end=2018\&locations=ID\&start=2000 [Accessed 112 2019].

[6] United States Geological Survey, 2016. Resource Nationalism in Indonesia - Effects of the 2014 Mineral Export Ban. [Online] Available at: http://pubs.er.usgs.gov/publication

[7] Warburton, E., 2017. Resource Nationalism in PostBoom Indonesia: The New Normal?. [Online] Available at: https://www.lowyinstitute.org/publications/resourcenationalism-post-boom-indonesia-new-normal [Accessed 2712 2019].

[8] Ward, H., 2009. Resource Nationalism and Sustainable Development: A Primer and Key Issue, s.1.: International Institute for Environment and Development.

[9] Wilson, J. D., 2009. Resource nationalism or resource liberalism? Explaining Australia's approach to Chinese investment in its minerals sector. Australian Journal of International Affairs, 65(3), pp. 283-304. 